\title{
Methods for improving teaching using student feedback techniques
}

\author{
Marti A. Dechesne
}

\section{OpenEdition}

\section{Journals}

\section{Electronic version}

URL: http://journals.openedition.org/asp/3896

DOI: 10.4000/asp.3896

ISSN: 2108-6354

\section{Publisher}

Groupe d'étude et de recherche en anglais de spécialité

\section{Printed version}

Date of publication: 1 December 1995

Number of pages: 231-240

ISSN: 1246-8185

\section{Electronic reference}

Marti A. Dechesne, «Methods for improving teaching using student feedback techniques », ASp

[Online], 7-10 | 1995, Online since 28 October 2013, connection on 20 April 2019. URL : http:// journals.openedition.org/asp/3896 ; DOI : 10.4000/asp.3896

This text was automatically generated on 20 April 2019.

Tous droits réservés 


\title{
Methods for improving teaching using student feedback techniques
}

\author{
Marti A. Dechesne
}

The teacher's purpose is to teach and the students' is to learn, but teachers can learn from students how to teach better. In the United States virtually every postsecondary facility utilizes some method of faculty or course evaluation. The evaluation of teaching can come from many sources: (1) self evaluation, (2) peer-evaluation, (3) classroom research techniques, and (4) faculty and course evaluations.

These techniques will be detailed, specific examples will be given, and an explanation will be included on how to develop a standard evaluation form. Although formal faculty/ course evaluation forms are sometimes used by facilities in the United States for the purpose of making personnel decisions, this will not be the focus of this article. The focus is on how to use feedback techniques to improve teaching.

\section{Evaluation as a component of curriculum design}

There are three major phases in curriculum design:

4 1. Development: The course or program is drafted specifying the goals and objectives, organization of the material, teaching methods, and material options.

5 2. Implementation: Once the program has been designed, the teacher implements it.

6 3. Evaluation: The course is assessed in terms of the effectiveness of teaching and how well the program meets the primary objectives.

7 Once an educational program is established, how can the teaching effectiveness be analyzed? Evaluation of the students' learning by test performance provides one measure of the success of the curriculum developed but there are also many methods to evaluate the effectiveness of teaching through the use of student feedback. These measures can run from informal meetings to standard teacher/course evaluation forms. 


\section{Reasons for evaluation}




\section{Methods of evaluation}

\section{Self-evaluation}

18 adapted from Maryellen Weimer (1990).

- What do you do with your hands? Gesture, play with the markers?

- Where do you stand or sit? At/on the table, always seated?

- When do you move to a different location? Never, at regular intervals, when you need to write something on the board, do you talk and move at the same time?

- Where do you move? Back to the table, out to the students, to the blackboard only?

- Where do your eyes most often focus? On your notes, on the board, out the window, on a spot on the wall above the students, could you tell who was in class today without having taken the roll?

- When do you speak louder or softer? When the point is very important, when nobody seems to understand, when nobody seems to be listening?

- When do you speak faster/slower? When an idea is important and you want to emphasize it, when you are behind in the syllabus, when students are asking questions that you're not sure of the answer?

- Do you laugh or smile in class? When, how often?

- How do you use examples? How often do you include them, when do you include them?

- How do you emphasize main points? Write them on the board, say them more than once, ask the students if they understand them, suggest ways they might be remembered?

- What do you do when students are inattentive? Ignore them, stop and ask questions, interject an anecdote, point out the consequences of not paying attention, move out toward them?

- Do you encourage student participation? How, do you call on students by name, do you grade them, how long do you wait for a response, do you verbally recognize a good response, do you correct students' answers, how much time is devoted to student talk?

- How do you begin/end class? With a summary and conclusion, with a preview and a review, with a gasp and a groan?

19 Another method of self-evaluation is to complete the same course evaluation form that is given to the students and then compare the results with the analysis of students' responses. (See course/faculty evaluation section). The differences between the teacher's responses and the students' ratings can be enlightening.

\section{Peer evaluation}

This method has generally not been very successful as a tool to identify areas that need improvement because peers generally do not like to «evaluate» their colleagues officially. Peer evaluation involves visiting a classroom at a pre-arranged time and reporting on the quality of the teaching for this class period using a standard evaluation form.

Several studies showed that most peers evaluated their colleagues highly and if given a vote most chose not to continue with this method, but classroom visitation was recommended as a method of sharing information and approaches rather than as an evaluation technique (Centra 1987). 


\section{Classroom research techniques} evaluation forms, which enables the instructors to control the feedback process. The most common factors identified as distinguishing characteristics of effective teaching are: command of subject, organization and clarity, instructor-group interactions, instructor-individual interactions and dynamism/enthusiasm (Dianda 1992; Fenton 1991; Katz 1988; Lewis 1991). Therefore it makes sense to include these areas on an evaluation form.

\section{Formats for evaluation instruments}

There are several formats for the evaluation instrument: open-ended questionnaire, closed-question instrument, checklist and inventories 
The most common form is a combination, closed-question instrument with a comments section (open-ended).

\section{Open-ended questionnaires}

31 All the forms basically cover the same areas. The five areas outlined as characteristics of effective teaching: command of subject, organization and clarity, instructor-group interactions, instructor-individual interactions, and dynamism/enthusiasm should be included on the form, regardless of the format chosen.

Open-ended questionnaires are longer to complete, but more constructive information may be obtained about what to change specifically in the program. Examples of openended question from each category are found in Table 1.

Table 1 Examples of open-ended questions

\begin{tabular}{|c|c|}
\hline Category & Example \\
\hline Command of subject & $\begin{array}{l}\text { The most relevant information that I learned from this course } \\
\text { is/was: } \\
\text { Knowledgeable. } \\
\text { Comments: }\end{array}$ \\
\hline Organization and clarity & $\begin{array}{l}\text { The concept that became clearer to me is/was: } \\
\text { Provided clear explanations. } \\
\text { Comments: }\end{array}$ \\
\hline Instructor-group interactions & $\begin{array}{l}\text { Challenged students. Comments: } \\
\text { Encouraged critical thinking. } \\
\text { Comments: }\end{array}$ \\
\hline Instructor-group interactions & $\begin{array}{l}\text { Challenged students. Comments: } \\
\text { Encouraged critical thinking. } \\
\text { Comments: }\end{array}$ \\
\hline $\begin{array}{l}\text { Instructor-individual } \\
\text { interactions }\end{array}$ & $\begin{array}{l}\text { How does the instructor promote student participation? } \\
\text { Provided feedback. Comments: } \\
\text { What I liked the most/least in the course: }\end{array}$ \\
\hline Dynamism/enthusiasm & $\begin{array}{l}\text { Professional role model. Comments: } \\
\text { Rapport with students and staff. } \\
\text { Comments: }\end{array}$ \\
\hline
\end{tabular}

\section{Closed question forms}

These are easier and faster to complete but lack specific information about what to do if the area is rated low. This problem can be eliminated if a comments section is added to 
each category or at the end. In the United States many of these forms are now computerized and can be read by a scanner. A printout of the results can be helpful to quickly identify patterns of strengths and weaknesses. This is probably the most common type of form. Examples of closed question forms can be found in Table 2.

Table 2 Examples of closed question items

\begin{tabular}{|c|c|}
\hline Category & Example \\
\hline Command of subject & $\begin{array}{l}\text { The instructor seemed knowledgeable in the subject matter. } \\
\text { Instructor demonstrates adequate knowledge of subject. }\end{array}$ \\
\hline Organization and clarity & $\begin{array}{l}\text { Instructor explains difficult materials clearly. } \\
\text { I received a course syllabus or course outline the first week of } \\
\text { class. } \\
\text { The material presented was well organized and well } \\
\text { integrated. }\end{array}$ \\
\hline Instructor-group interactions & $\begin{array}{l}\text { The lecturer used our names. } \\
\text { The class size was conducive to active student learning. }\end{array}$ \\
\hline $\begin{array}{l}\text { Instructor-individual } \\
\text { interactions }\end{array}$ & $\begin{array}{l}\text { Students felt free to disagree with the instructor. } \\
\text { Provided constructive feedback. } \\
\text { I learned a great deal from this course. }\end{array}$ \\
\hline Dynamism/enthusiasm & $\begin{array}{l}\text { The instructor seemed to enjoy teaching. } \\
\text { The instructor was successful in making the class interesting. } \\
\text { The lecturer was dynamic. } \\
\text { I would like to take another course in this area. }\end{array}$ \\
\hline
\end{tabular}

The rating scales for the responses to closed question instruments are varied. There is a continuum of responses that not only identifies the strengths or weaknesses, but also helps to define the magnitude of the item. Examples of scale ratings that can used after the question are shown in Table 3.

Table 3 Scale ratings

\begin{tabular}{|l|l|l|}
\hline Key rating & Key rating & Key rating \\
\hline 0. Not applicable & A Excellent & Never \\
\hline 1. Strongly Disagree & B Very good & Seldom \\
\hline 2. Disagree & C Acceptable & Sometimes \\
\hline 3. Neutral & D Needs improvement & Frequently \\
\hline 4. Agree & F Unacceptable & Always \\
\hline
\end{tabular}




\begin{tabular}{|l|l|l|}
\hline 5. Strongly Agree & NA Not applicable & \\
\hline
\end{tabular}

\section{Checklists}

Checklists simply identify the absence or presence of a particular behavior which can be helpful to distinguish areas of strength or weakness but not necessarily their magnitude. The items on the evaluation form would be the same as for closed question formats but instead of a range of responses the student simply checks yes or no.

\section{General advice}

- Construct a professional-looking form.

- «\#TOUTMAJUSCULES\#> >\#GRAS\#></\#GRAS\#></\#TOUTMAJUSCULES\#>Look at results in terms of trends, not - Am I good or bad?

- $<$ \#TOUTMajuscules\#><\#TOUTMAJUSCULES\#>Give forms before the end of class -allow at least 15-20 minutes

- $<$ \#OUTMAJuscules\#><\#TOUTMAJUSCULES\#>Include a comments section even with closedquestion instruments.

- «\#TOUTMAJUSCULES\#>/\#TOUTMAJUSCULES\#>Allow anonymity.

- $<\#$ TOUTMAJUSCULES\#><\#GRA\#>>\#GRAS\#></\#TOUTMAJUSCULES\#>Ask only those questions that need an answer.

- <\#TOUTMAJUSCULES\#>/\#TOUTMAJUSCULES\#>Keep it simple.

Evaluation can be perceived as a threat to the implied power of the teacher, but in reality, personal and concrete feedback can be used as a source of inspiration and encouragement. Informed and useful feedback can invite faculty to reflect on methods to improve teaching practices and communication with students see Appendix). Shouldn't improved teaching lead logically to improved learning? Change can only come from a desire to apply the information gathered.

Thanks to Dr. Marcia Wratcher (Carnegie Mellon University) for her valuable assistance and input.

\section{BIBLIOGRAPHY}

Aleamoni L. M. 1987. “Typical faculty concerns about student evaluation of teaching”. In Aleamoni, L. M. (ed.), Techniques for Evaluating and Improving Instruction. San Francisco: JosseyBass, 25-31.

Centra J. A. 1987. "Formative and summative evaluation: Parody or paradox?". In Aleamoni, L. M. (ed.), Techniques for Evaluating and Improving Instruction. San Francisco: Jossey-Bass, 47-55.

Dianda, M. 1992. “Promoting beginning teachers' success in teaching linguistically diverse students: A synthesis of relevant knowledge and practice". Washington, D.C.: Office of Educational Research and Improvement (ERIC Document Reproduction Service No. ED 346 104).

Fenton, E. 1991. Evaluating Teaching to Improve Instruction, Communiques about teaching. Pittsburgh, PA: The University Teaching Center of Carnegie Mellon. 
Gil, D. H. 1987. “Instructional evaluation as a feedback process”. In Aleamoni, L. M. (ed.), Techniques for Evaluating and Improving Instruction. San Francisco: Jossey-Bass, 57- 64.

Katz, R. 1988. “An effective teacher: The students' point of view”. Paper presented at the 22nd annual meeting of the Teachers of English to Speakers of Other Languages, Chicago IL, March 8-13 (ERIC Document Reproduction Service No. ED 304 017).

Lewis, K. 1991. "Gathering data for the improvement of teaching: What do I need and how do I get it?". In Theall, M. and J. Franklin (eds.), Effective Practices for Improving Teaching. San Francisco: Jossey-Bass.

McKeachie, W. 1994. Teaching Tips (9th ed.). Lexington, MA: D. C. Heath \& Co.

Ornstein, A. \& F. Hunkins. 1993. Curriculum: Foundations, principles, and theory (2nd ed.). Boston: Allyn and Bacon.

Weimer, M. 1990. Improving College Teaching: Strategies for developing instructional effectiveness. San Francisco: Jossey-Bass.

Wennerstrom, A. \& P. Heiser. 1992. “ESL student bias in instructional evaluation”. TESOL Quarterly 26, 271-288.

\section{ABSTRACTS}

Teachers can learn from students how to teach better. There are many ways to get feedback to evaluate the quality of teaching: self-evaluation, peer-evaluation, classroom research techniques, and faculty/course evaluations. Virtually every post-secondary educational facility in the United States utilizes some method of faculty/course evaluation. The success of improving teaching depends on the quality of the information gathered and the desire to apply the information.

Les professeurs peuvent apprendre des élèves comment mieux enseigner. Il y a de nombreuses façons d'avoir des retours pour évaluer la qualité de l'enseignement: l'auto-évaluation, l'évaluation par les collègues, les techniques de recherche dans les cours et les évaluations des enseignants ou des cours. Presque tous les établissements d'enseignement supérieur aux ÉtatsUnis utilisent des méthodes d'évaluation des enseignants ou des cours. Le succès de l'amélioration de l'enseignement dépend de la qualité des informations amassées et du désir de les appliquer.

\section{INDEX}

Mots-clés: évaluation des cours, évaluation des enseignants, retour des étudiants

Keywords: course evaluation, faculty evaluation, student feedback

\section{AUTHOR}

\section{MARTI A. DECHESNE}

Marti A. Dechesne teaches at Institut de Formation et de Communication des Entreprises (IFCE), Nîmes. 